\title{
PERBANDINGAN MODEL PEMBELAJARAN DISCOVERI LEARNING DAN MODEL PEMBELAJARAN PROBLEM POSING UNTUK MENINGKATKAN HASIL BELAJAR KONSEP SISTEM PENCERNAAN MAKANAN PADA SISWA KELAS VIII SMP KRISTEN YPKPM AMBON
}

\author{
Dominggas Radjangolo', H. Tuaputty ${ }^{2}$, Ine Arini ${ }^{2}$ \\ ${ }^{1}$ Alumni Program Studi Pendidikan Biologi \\ 2Dosen Program Studi Pendidikan Biologi \\ E-mail: tuaputtyhasan123@gmail.com
}

\begin{abstract}
Background: The use of the right learning model is an alternative to overcome the problem of students' low absorption of lessons, in order to improve the quality of teaching. In its implementation, an appropriate learning model is needed that is able to arouse students' motivation to learn. The use of the right learning model is to use Discovery Learning models and Problem Posing learning models.

Method: This study aims to determine the differences in student learning outcomes taught using Discovery Learning models and Problem Posing learning models on the concept of the digestive system in the food of class VIII students of YPKPM Christian Middle School Ambon.

Results: Based on the results of the study the use of the Discovery learning model the average value of cognitive aspects $=87.82$, the affective aspect $=80.88$, the psychomotor aspects $=90.4$, the final value $=94.64$, the final test value $=94$. While the model Problem Posing learning the average value on cognitive aspects $=95.49$, affective aspects $=93.76$, psychomotor aspects $=93.32$, final value $=$ 93.90 and final test value $=96.17$. With $\mathrm{t}$ count 2.04 and $\mathrm{t}$ table 2.01 .

Conclusion: Student learning outcomes in the problem posing learning model class are higher than students in the class of discovery learning models.
\end{abstract}

Keywords: Learning model, problem posing, discovery learning.

\begin{abstract}
Abstrak
Latar Belakang: Penggunaan model pembelajaran yang tepat merupakan suatu alternatif mengatasi masalah rendahnya daya serap siswa terhadap pelajaran, guna meningkatkan mutu pengajaran. Dalam pelaksanaannya diperlukan model pembelajaran yang sesuai yang mampu membangkitkan motivasi siswa untuk belajar. Penggunaan model pembelajaran yang tepat adalah dengan menggunakan model pembelajaran Discovery Learning dan model pembelajaran Problem Posing.

Metode: Penelitian ini bertujuan untuk mengetahui perbedaan hasil belajar siswa yang diajarkan dengan menggunakan model pembelajaran Discoveri Learning dan model pembelajaran Problem Posing pada konsep sistem pencernaan pada makanan siswa kelas VIII SMP YPKPM Kristen Ambon.

Hasil: Berdasarkan hasil penelitian penggunaan model pembelajaran Discovery learning nilai rata-rata aspek kognitif $=87,82$, aspek afektif $=80,88$, aspek psikomotor $=90,4$, nilai akhir $=94,64$, nilai tes akhir $=94$. Sedangkan model pembelajaran Problem Posing nilai rata-rata pada aspek kognitif $=$ 95,49, aspek afektif $=93,76$, aspek psikomotor $=93,32$, nilai akhir $=93,90$ dan nilai tes akhir $=96,17$. Dengan nilai $t_{\text {hitung }} 2,04$ dan $t_{\text {tabel }} 2,01$.

Kesimpulan: Hasil belajar siswa pada kelas model pembelajaran problem posing lebih tinggi dari siswa pada kelas model pembelajaran discovery learning.
\end{abstract}

Kata kunci: Model pembelajaran, problem posing, discovery learning. 


\section{PENDAHULUAN}

Pendidikan merupakan hal yang utama dalam peningkatan kualitas sumber daya manusia yang dapat mempengaruhi berbagai bidang di dalam pengembangan dan pembangunan bangsa. Upaya yang dilakukan untuk memperoleh sumber daya manusia yang berkualitas yakni melalui pendidikan. Undang-undang Republik Indonesia No. 20 Tahun 2003 pasal 1 (ayat 1), pendidikan adalah usaha sadar dan terencana untuk mewujudkan suasana belajar dan proses belajar agar siswa secara aktif mengembangkan potensi dirinya untuk memiliki kekuatan spiritual, keagamaan, pengendalian diri, kepribadian, kecerdasan, akhlak mulia, serta keterampilan yang diperlukan untuk dirinya, masyarakat, bangsa, dan negara. Oleh karena itu, pendidikan diselenggarakan dengan memberi keteladanan, membangun kemauan, dan mengembangkan kreativitas siswa dalam proses pembelajaran.

Umunya tujuan pendidikan adalah menyediakan lingkungan yang memungkinkan anak didik untuk mengembangkan bakat dan kemampuannya secara optimal. Setiap orang memiliki potensi kemampuan dalam derajat yang berbeda-beda dan dalam bidang yang berbeda pula. Peserta didik dapat mewujudkan dirinya dan berfungsi sepenuhnya sesuai dengan kebutuhan pribadinya dan kebutuhan masyarakat. Salah satu komponen pendidikan adalah peserta didik dan pendidik,peserta didik adalah komponen masuknya dalam sistem pendidikan, yang selanjutnya diproses dalam proses pendidikan, sehingga menjadi manusia yang berkualitas sesuai dengan tujuan pendidikan nasional.

Apabila hal ini dibiarkan terus akan menyebabkan siswa semakin mengalami kesulitan dalam mempelajari dan memahami konsep-konsep yang ada dalam pembelajaran biologi dan guru juga akan menalami kesulitan dalam memberi materi kepada siswa karena pembelajaran cenderung satu arah,sehingga pada gilirannya proses pembelajaran menjadi terlambat.

Menurut Trianto (2010:5-9) pada kenyataan yang dilihat disekolah guru masih mendominasi dalam pembembelajaran sementara itu siswa kurang untuk mendapatkan sesempatan untuk mengembangkan proses berpikirnya secara mandiri akibatnya siswa pasif. Hal tersebut menjadikan tidak efektif interaksi yang terjadi antara guru dan siswa. Kondisi pembelajaran yang kurang efektif dapat tercipta dengan mengelola proses pembelajaran sehingga hasi dari pembelajaran tersebut siswa memperoleh suatu perubahan tingkah laku sbagai hasil dari pengalaman siswa dalam interaksidengan lingkungannya yang menyangkut kognitif, afektif, dan psikomotor.

Berdasarkan hasil observasi, proses pembelajaran biologi yang berlangsung satu arah yaitu guru ke siswa. Proses pembelajaran masi mendominasi guru mata pelajaran biologi dengan menggunakan model pembelajaran ceramah. Kondisi tersebut membuat siswa tidak maksimal dalam mengikuti pelajaran. Siswa terlihat bosan dalam penyampaian materi, kurang semangat dalam belajar dan sulit memahami materi yang disampaikan guru. Selain itu, pada saat guru menerangkan materi ada beberapa siswa yang asik mengobrol sendiri bahakan ada siswa yang tertidur di kelas. Hal ini terlihat hampir tidak adanya siswa yang bertanya ataupun mengemukakan pendapat, dan kurang partisipasi siswa menjawab pertanyaan guru sehingga sulit untuk mengetahui sejauh mana pemahaman siswa terrhadap materi pelajaran terkhususnya pada materi sistem pencernaan makanan.

Untuk memperbaiki keadaan tersebut dengan mengaplikasikan model pembelajaran Discoveri Learning dan model Problem Posing. Model Discoveri Learning menempatkan siswa pada kondisi pemahaman arti dan penggalian makna dengan belajar memahami konsep, arti,dan hubungan melalui proses intuitif untuk akhirnya sampai pada suatu kesimpulan. Dengan mengaplikasikan model Discoveri Learning dalam mata pelajaran biologi diharapkan berdampak positif dan membawa perubahan dalam kehidupan sehari- hari, siswa diharapkan mempunyai motivasi belajar yang lebih tinggi dan terus meningkat. Belajardengan lebih mandiri, berpikir kreatif dalam memecahkan berbagai permasalahan yang diberikan. Sedangkan model Problem Posing 
merupakan istilah dalam bahasa inggris yang berasal dari dua kata yaitu "Problem" yang artinya masalah atau soal, dan Posing" dari kata to pose yang berarti mengajukan atau membentuk, sebagai padanan istilah dalam bahasa Indonesia " Pembentukan Soal" atau "Pengajuan Soal. Atau model pembelajaran problem posing merupakan pembelajaran yang menekankan siswa mengajukan pertanyaan sendiri atau memecahkan soal menjadi perutanyaan-pertanyaan yang lebih sederhana yang mengacuh pada penyelesaian soal tersebut (Puspitasari 2011:11).

Problem posing diharapkan dapat menciptakan pembelajaran yang efektif. Sesuai pendapat Hamalik (2005:17) pembelajaran efektif adalah pembelajaran yang menyediakan kesempatan kepada siswa untuk belajar mandiri, sehingga dengan melakukan aktivitas belajar siswa mampu memperoleh pemahaman sendiri. Dapat kita lihat dari kedua model pembelajaran tersebut sangat berpengaruh positif dalam proses pembelajaran. mengingat permasalahan yang sering dialami siswa SMP Kristen YPKPM salah satunya rendah hasil belajar, baik kognitif afektif dan psikomotor hampir setiap tahun pemahaman siswa terhadap konsep sistem pencernaan tidak mencapai nilai KKM dengan nilai kurang dari 75 mata pelajaran biologi

\section{MATERI DAN METODE}

Adapun tipe penelitian ini adalah penelitian eksperimen semu yang bertujuan untuk mengetahui perbandingan hasil belajar siswa IPA materi tentang sistem pencernaan makanan yang diajarkan dengan menerapkan model pembelajaran Discoveri Learning dan Problem Posing.

Data dalam penelitian ini kemudian diolah menggunakan analisis deskriptif.

$\mathrm{SP}=\frac{\text { Skor perolehan }}{\text { Skor maksimum }} \times 100$

Selanjutnya Nilai proses (NP) diperoleh dengan cara :

$\mathrm{NP}=$

Nilai Kognitif + Nilai Afektif $+N i$ 回i Psikomotor

$\mathrm{NA}=\frac{6 P+4 f}{10}$
Keterangan :

NA : Nilai Akhir

$P$ : Nilai Proses

$F \quad$ : Nilai hasil tes formatif setelah proses pembelajaran

Setelah memperoleh nilai akhir maka selanjutnya di lakukan uji tanda (t test) dengan rumus: $\mathrm{t}=\frac{\bar{x}_{1}-\bar{x}_{2}}{\sqrt{\left(\frac{S S_{1}+S S_{2}}{n_{1}+n_{2}-2}\right)\left(\frac{1}{n_{1}}+\frac{1}{n_{2}}\right)}}$

Mengadopsi dari Sumanto, 2010)

\section{Dimana:}

$\bar{x}_{1}=$ nilai rata-rata siswa kelas Problem posing

$\bar{x}_{2}=$ nilai rata-rata siswa kelas discoveri Learning

$\mathrm{S}_{1}=$ simpangan baku kelas problem posing $\mathrm{S}_{2}=$ simpangan baku kelas discoveri learning

$\mathrm{n}_{1}=$ jumlah siswa kelas problem posig

$\mathrm{n}_{2}=$ jumlah siswa kelas discoveri learning dengan criteria: terima $\mathrm{Ha}$ jika $t_{h i t}>$ dari $t_{t a b}$.

$\mathrm{H}_{0} t_{\text {hit }}<$ dari $t_{t a b}$.

Untuk menghitung rata-rata maka penggunaan rumus:

$\bar{x}=\frac{\sum x}{n}$

Dimana:

$\bar{x}=$ rata-rata hitung.

$\sum x=$ jumlah total nilai siswa.

$\mathrm{n}=$ jumlah sampel.

Sedangkan untuk menghitung simpangan baku rumusnya sebagai berikut:

$\mathrm{SS}=\sum x^{2}-\frac{\left(\sum x\right)^{2}}{n} \quad$ (Sumanto 2010)

Dimana:

$\mathrm{SS}=$ simpangan baku .

$\sum x=$ jumlah total nilai siswa.

$\mathrm{n}=$ jumlah sampel

\section{HASIL DAN PEMBAHASAN}

Model ini disesuaikan dengan tujuan yang ingin dicapai oleh pembelajaran pada berbagai mata pelajaran, meliputi aspek kemampuan mengemukakan pendapat, kemampuan menganalisis masalah, 
kemampuan menulis pendapatpendapatnya setelah melakukan pengamatan, kemampuan menyimpulkan, memberikan kesempatan dan menuntut siswa terlibat aktif didalam mencapai tujuan pembelajaran dengan memberikan bantuan secara bertahap sehingga siswa dapat membuat pertanyaan (Hisyam, 2008).

Model pembelajaran discoveri learning memiliki langkah-langkah pembelajaran yang terdiri Orientasi siswa pada masalah, merumuskan hipotesis, Melakukan kegiatan penemuan, Mempresentasikan hasil penemuan, Mengevaluaasi kegiatan penemuan.

Langkah-langkah pembelajaran problem posing adalah siswa mengajukan dan menjawab soal dengan berkelompok berdasarkan penjelasan guru ataupun pengalaman siswa itu sendiri. Maka, langkah-langkah yang digunakan dalam penelitian ini adalah 1) menjelaskan materi pelajaran dengan media yang telah disediakan, 2) membagi siswa menjadi kelompok secara heterogen, 3) secara berkelompok, siswa mengajukan pertanyaan pada lembar soal, 4) menukarkan lembar soal pada kelompok lainnya, 5) menjawab soal pada lembar jawab, dan 6) mempresentasikan lembar soal dan lembar jawab di depan kelas.

\section{Deskripsi Penguasaan Tes Awal Siswa (Pre-Test)}

Tes awal digunakan dengan tujuan untuk mengetahui pemahaman siswa pada konsep lingkungan, yang dilakukan sebelum proses belajar mengajar. Kualifikasi rata-rata skor pencapaian siswa pada tes awal terdapat pada tabel 4.1 yang menunjukkan bahwa kemampuan awal siswa sangat rendah. Hal ini terbukti dengan 25 siswa (100\%) berada pada kualifikasi kurang.

Tabel 1. Kualifikasi Skor Pencapaian Siswa Pada Tes Awal

\begin{tabular}{cccccc}
\hline Interval & Kelas Discoveri learning & $\begin{array}{c}\text { Kelas Problem } \\
\text { Posing }\end{array}$ & Kualifikasi \\
\hline $90-100$ & - & - & - & - & Sangat baik \\
$80-89$ & - & - & - & - & Baik \\
$75-79$ & - & - & - & - & Cukup \\
$<75$ & 25 & 100 & 25 & 100 & Gagal \\
Jumlah & $\mathbf{2 5}$ & $\mathbf{1 0 0 \%}$ & $\mathbf{2 5}$ & $\mathbf{1 0 0 \%}$ & Gagal \\
\hline
\end{tabular}

Pada tabel 1 terlihat hasil pencapaian siswa pada tes awal, dimana pada interval $\geq 75$ tidak ada siswa yang memiliki nilai dengan kualifikasi tuntas, dan pada interval $\leq 75$ terdapat 25 siswa (100\%) berada pada kualifikasi gagal yang belum mampu menguasaiindikator-indikator pembelajaran yang akan dipelajari. Berdasarkan hasil penelitian yang diperoleh pada siswa kelas $\mathrm{VIII}^{1}$ dan kelas VIII ${ }^{2}$ SMP Kristen YPKPM Ambon, sebelum melakukan kegiatan belajar mengajar (KBM) siswa diberikan tes awal (pretest), tabel 4.1 terlihat hasil pencapaian siswa pada tes awal, dimana pada interval $\leq 75$ terdapat 25 siswa (100\%) berada pada kualifikasi kurang dengan ratarata skor pencapaian pada model discoveri learning 29,22 sedangkan untuk model problem posing tabel 4.1 terlihat hasil pencapaian siswa pada tes awal, dimana pada interval $\leq 75$ terdapat 25 siswa (100\%) berada pada kualifikasi kurang dengan ratarata skor pencapaian pada model discovery learning 35,64. Tes ini dilakukan dengan tujuan untuk mengetahui tingkat pemahaman awal siswa terkait dengan konsep sistem pencernaan makanan dan juga untuk membentuk kerja kelompok siswa dengan tingkat kemampuan berbeda.

Peningkatan terhadap hasil belajar perlu adanya model yang dapat mendukung proses pembelajaran, maka peneliti menerapkan suatu model pembeaaran yakni, model pembelajaran problem posing dan model pembelaajjaran discoveri learning yang merupakan model yang 
mudah mendapatkan pertisipasi seluruh kelas dan pertanggung jawaban individu. Model discoveri learning ini memberi kesempatan kepada siswa untuk siswa belajar melalui keterlibatan aktif dan guru mendorong siswa untuk mendapatkan pengalaman dengan melakukan kegiatan yang memungkinkan karena menemukan prinsip-prinsip untuk diri mereka sendiri. Sedangkan model problem posing " dari kata to pose yang berarti mengajukan atau membentuk, sebagai padanan istilah dalam bahasa Indonesia " pembentukan soal” atau "pengajuan soal.

Deskripsi Tingkat Penguasaan Siswa Selama Proses Pembelajaran Kemampuan Kognitif Siswa

Data kemampuan kognitif siswa yang selama proses pembelajaran dengan menerapkan model pembelajaran discoveri learning dan Problem posing dapat dilihat melalui persentase LKS. Kualifikasi ratarata skor pencapaian siswa pada LKS terlihat pada tabel 2.

Tabel 2. Kualifikasi hasil belajar siswa pada aspek kognitif

\begin{tabular}{llllll}
\hline \multirow{2}{*}{ Interval } & \multicolumn{2}{c}{ Discoveri Learning } & \multicolumn{2}{c}{ Problem Posing } & \multirow{2}{*}{ Kualifikasi } \\
\cline { 2 - 5 } & Frekwensi & Presentase & Frekwensi & $\mathbf{1 0 0 \%}$ & \\
\hline $90-100$ & 9 & 36 & 15 & 60 & Sangat baik \\
$80-89$ & 16 & 64 & 10 & 40 & Baik \\
$75-79$ & - & - & - & - & Cukup \\
$<75$ & 25 & 100 & 25 & 100 & Gagal \\
\hline
\end{tabular}

Tabel 2 menunjukkan hasil pencapaian siswa pada aspek kognitif, dimana pada interval $\geq 75$ terdapat 25 siswa (100\%) yang memiliki nilai ini dengan kualifikasi tuntas, dan pada interval $\leq 75$ tidak terdapat siswa pada posisi ini, dengan kualifikasi gagal, jika dibandingkan antar nilai KKM dengan rata-rata skor pencapian siswa pada aspek kognitif, maka dapat dikatakan pencapian kemampuan kognitif siswa berada pada kulaifikasi tuntas dengan rata-rata skor pencapaian pada model discoveri learning Dalam proses pembelajaran pada tabel 2 menggambarkan aspek kognitif siswa dilihat dari hasil belajar pada lembar kerja siswa dan tes akhir, sebanyak 25 siswa (100\%) orang siswa berada pada interval $\geq 75$, dengan nilai rata-rata pencapaian pada model discoveri learning adalah 91,12 sedangkan pada model problem posing 93,90 .

\section{Kemampuan Afektif Siswa}

Aspek afektif merupakan aspek yang berkaitan dengan sikap siswa selama proses pembelajaran terlihat hasil pencapaian siswa pada aspek afektif, dimana pada interval $\geq 75$ terdapat 25 siswa $(100 \%)$ yang memiliki nilai ini dengan kualifikasi tuntas dengan rata-rata skor pencapian model discoveri learning adalah 90,88 Dan model problem posing $=93,76$.
Hasil ini membuktikan bahwa dalam proses pembelajaran siswa mampu merespon dengan baik proses pembelajaran yang berlangsung.

\section{Kemampuan Psikomotor Siswa}

Data mengenai kemampuan psikomotor siswa menunjukkan rata-rata skor pencapaian berada pada kualifikasi tuntas. Aspek psikomotor mencakup keterampilan siswa yang berlangsung selama proses pembelajaran dinilai melalui lembar observasi, kemampuan psikomotor selama proses pembelajaran telah tersaji dalam tabel 4.4. terlihat hasil pencapaian siswa pada aspek psikomotor, dimana pada interval $\geq 75$ terdapat 25 siswa (100\%) yang memiliki nilai ini dengan kualifikasi tuntas dengan rata-rata skor pencapian adalah 80,93 . Setelah melakukan proses belajar mengajar (PBM) dengan model problem posing dan discoveri learning dalam pembelajaran biologi pada pertemuan I dan II sebanyak 0 siswa $(0 \%)$ mendapatkan nilai memenuhi KKM adalah 25 orang siswa (100\%). Hasil belajar psikomotor sebenarnya tahap lanjutan dari hasil belajar afektif yang baru nampak dalam kecenderungan-kecenderungan untuk berperilaku (Sudjana, 2010).

Deskripsi Tes Akhir (Post-Test) 
Pada proses belajar mengajar telah selesai, maka akan dilakukan tes akhir untuk menunjukan kemampuan pola pikir siswa dengan materi yang telah diajarkan, pencapaian kemampuan siswa berada pada kategori tuntas. Tes akhir bertujuan untuk mengetahui tingkat keberhasilan baik dari segi guru maupun siswa, Tes formatif merupakan tes yang diberikan kepada siswa ketika siswa tersebut telah melalui suatu proses belajar mengajar, fungsinya adalah untuk mengetahui apakah siswa tersebut memang benar-benar telah tuntas dalam mempelajari indikator-indikator pembelajaran konsep lingkungan yang diberikan dengan menerapkan model problem posing dan discoveri. Kualifikasi pencapain hasil tes formatif pada tabel 4.5 terdapat 25 siswa (100\%) yang memiliki nilai ini dengan kualifikasi tuntas, dengan rata-rata skor pencapaian 91,71. Proses pembelajaran serta dilakukannya evaluasi formatif penentuan untuk seoarang siswa dapat dikatakan berhasil dalam setiap proses yang berlangsung adalah perolehan nilai akhir. Nilai akhir merupakan nilai yang menandakan tingkat keberhasilan yang dicapai siswa setelah mengikuti kegiatan belajar mengajar, hasil perolehan nilai akhir yang diperoleh dari tabel 4.6 dengan interval $\geq 75$ terdapat 20 siswa $(100 \%)$ yang memiliki nilai ini dengan kualifikasi tuntas, dengan rata-rata skor pencapaian secara klasikal yaitu 91,07.

\section{Deskripsi Nilai Akhir Siswa}

Hasil belajar merupakan pengalaman belajar yang di miliki siswa, yang dapat di amati dan di ukur dalam perubahan- perubahan sikap dan ketrampilan (Hamalik, 2005). Setiap proses proses belajar mengajar selalu menghasilkan hasil belajar, masalah yang dihadapi adalah sampai ditingkat mana presentasi hasil belajar yang dicapai (Djamarah, 2013). Setelah dilakukan pembelajaran dengan menerapkan model pembelajaran discoveri Learning dan problem posing pada konsep sistem perncernaan makanan, pencapaian nilai akhir (NA) menggambarkan tingkat pencapaian penilaian afektif, psikomotor, kognitif serta pencapaian pada tes akhir. dikatakan pencapaian kemampuan akhir siswa beradapada kualifikasi tuntas dengan rata-rata skor pencapaian untuk discoveri learning $=91.12$ dan problem posing 93,90. Menerapkan model problem posing dan discoveri sangat berperan penting dalam proses belajar mengajar, karena hasil belajar siswa dapat tercapai secara keseluruhan dengan baik

\section{Hasil Analisis Perbandingan Problem posing dan discoveri Learning}

Dari hasil nilai akhir maka dilakukan perhitungan dengan menggunakan uji $t$ maka hasil $t^{\text {hitung }}$ adalah 2,04 maka ha di terima dan ho ditolak. Yang memperlihatkan bahwa ada perbedaan hasil belajara siswa kelas yang diajarkan dengan model discoveri learning dan model Problem posing. Hasil belajar siswa dapat dikatakan berkualitas apabila siswa secara sadar mampu mengontrol proses kognitifnya secara berkesinambungan dan berdampak pada peningkatan kemampuan metakognitif (Yula Miranda, 2010).

Tabel 3. Hasil Analisis Perbandingan Problem posing dan discoveri Learning

\begin{tabular}{ccccc}
\hline \multicolumn{1}{c}{ Kelas } & Mean & SB & $\mathbf{t}_{\text {hitung }}$ & $\mathbf{t}_{\text {tabel }}$ \\
\hline Problem posing & 96.17 & 282,78 & 2,04 & 2,01 \\
Discovery learning & 94,43 & 596,48 & 2,04 & 2 \\
\hline
\end{tabular}

\section{KESIMPULAN}

Berdasarkan hasil penelitian yang dilakukan pada SMP KRISTEN YPKPM AMABON. Dengan judul 'Perbandingan Model Pembelajaran Discoveri Learning Dan Problem Posing Untuk Meningkatkan Hasil Belajar Konsep Sistem Pencernaan
Makanan Pada Siswa Kelas VIII SMP KRISTEN YPKPM AMBON". Berdasarkan uji perbandingan yang dilakukan pada kelas yang menggunakan model pembelajaran discovery learning dan kelas yang menggunakan model pembelajaran problem posing maka terdapat perbedaan hasil 
belajar pada materi sistim pencernaan makanan. Hasil belajar siswa pada kelas model pembelajaran problem posing lebih tinggi dari siswa pada kelas model pembelajaran discovery learning.

\section{DAFTAR PUSTAKA}

Djamarah, S.B. \& Zain, B. 2013. Strategi belajar mengajar. Jakarta: PT. Rineka Cipta

Hamalik, O (2005). Perencanaan pengajaran Berdasarkan Pendekatan Sistem, Jakarta PT. Bumi Aksara

Hisyam Zaini. 2008. Strategi Pembelajaran Aktif. Yogyakarta: Insan Mandiri

Kunandar. 2007. Guru Profesional. Jakarta: PT Raja Gafindo Persada

Miranda.Yula 2010. Strategi-Strategi Pembelajaran untuk Penelitian
Tindakan Kelas. Malang: Penerbit Surya Gemilang

Puspitasari, Dian.,2011 Penggunaan Model Pembelajaran Problem Posing untuk Meningkatkan Kemampuan Pemahaman matematis Siswa Sekolah Menengah Pertama kelas VIII SMP Negeri 2 Purwakarta (Skripsi) Universitas Pendidikan Indonesia, Bandung

Sumanto A., (2010). Teaching Modern Scince. Sixth Edition. New York: Merrill Publishers

Sudjana, Nana.2010 Penilaian Hasil Proses Belajar.Bandung PT Remaj. Rosdakarya

Trianto. (2010). Model Pembelajaran Inovatif Berorintasi Kontruktivistik. Jakarta: Prestasi Pustaka.

Undang-Undang No. 20 Tahun 2003 tentang Sistem Pendidikan Nasional. 